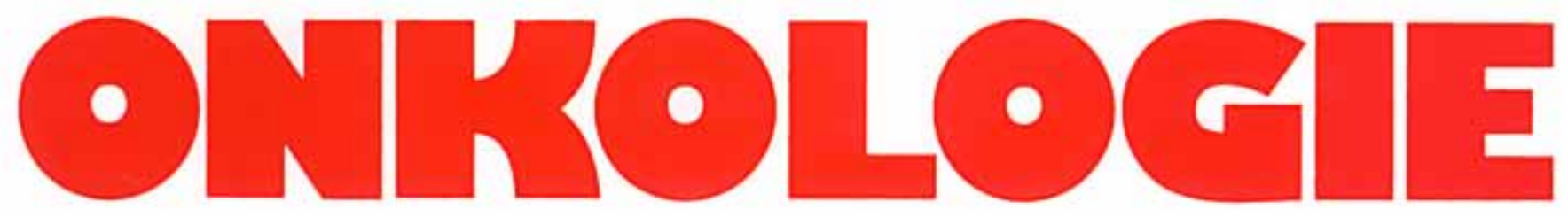

International Journal for Cancer Research and Treatment

Sonderheft 1 zu Band 21 Januar 1998

\section{Tumortherapie - State of the Art}

3. Kongress des Tumorzentrums Freiburg

2. -6 . Februar 1998

Gast-Herausgeber:

M. Brandis und W. Koch, Freiburg i.Br.

\section{Abstracts}

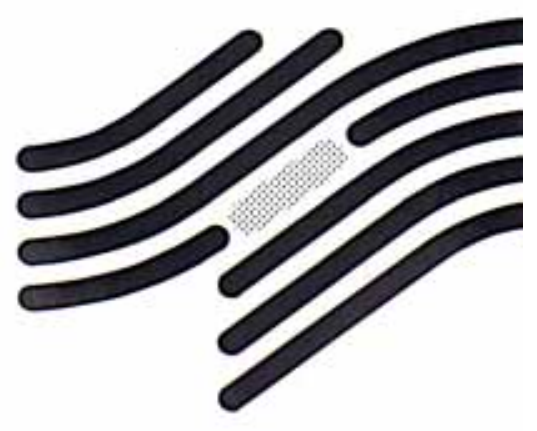

S. Karger

Verlag fir Medizin und

Naturwissenwhaften Gimbll

Basel - Freiburg

Patis - London

New Yotk + New Delhi

Basghok - Singapred

Tokyo - Sydney

\section{nline}

Artikel (Volltext) und Inhaltsverzeichnisse

sowie das vorlaufige Inhaltsverzeichnis des nächsten Heftes:

www.karger.com/joumals/onkjonkcont. htm 
This issue contains the abstracts of the 3. Kongress des Tumorzentrums Freiburg

2.-6. Februar 1998

and is not available online for technical reasons. 